\title{
The effect of chemotherapeutics on cell-to-cell transport of HTLV-1 and the p8 protein through membrane nanotubes
}

\author{
M Omsland ${ }^{1,2^{*}}$, C Pise-Masison², BT Gjertsen ${ }^{1,3}$, G Franchini ${ }^{2}$, V Andresen ${ }^{1}$ \\ From 17th International Conference on Human Retroviruses: HTLV and Related Viruses \\ Trois Ilets, Martinique. 18-21 June 2015
}

The tunneling nanotube (TNT) is a novel type of cellto-cell communicator, $50-2 \mathrm{~nm}$ in diameter, $\mathrm{F}$-actin containing structure connecting two or more cells. TNTs have been observed in a variety of cells to transport different components such as mitochondria, cell membrane components, multi-resistance genes and pathogens (like retroviruses and bacteria). The exact molecular mechanisms behind TNT formation are still unclear. HTLV-1 hijacks TNT-like structures for its transmission through the viral encoded $\mathrm{p} 8$ protein that augments the number and length of these TNT-like structures to favor virus transmission among T-cells. We have previously investigated TNTs in the heterogeneous and aggressive blood cancer, acute myeloid leukemia (AML), and found that the chemotherapeutic cytarabine (AraC) down-regulates TNT production in AML cells. Thus we wish to apply this knowledge to investigate whether AraC may exert a similar effect in T-cells and monocytes resulting in decreased HTLV-1 transmission. Furthermore we will measure the drug's effect on the transfer of the $\mathrm{p} 8$ protein to uninfected cells such as primary PBMCs, Jurkat T cells and THP-1 cells. We have generated Jurkat T and THP-1 cells stably expressing mem-GFP and mem-Cherry proteins for livecell visualization of TNT and TNT-like structures by fluorescence microscopy. The results will be presented.

\section{Authors' details}

${ }^{1}$ Centre for Cancer Biomarkers CCBIO, Department of Clinical Science,

Translational Hemato-Oncology Group, University of Bergen, Bergen, Norway.

${ }^{2}$ Animal Models and Retroviral Vaccine Section, Vaccine Branch, National

\footnotetext{
* Correspondence: Maria.Omsland@k2.uib.no

${ }^{1}$ Centre for Cancer Biomarkers CCBIO, Department of Clinical Science,

Translational Hemato-Oncology Group, University of Bergen, Bergen, Norway Full list of author information is available at the end of the article
}

Cancer Institute, National Institutes of Health, Bethesda, Maryland, USA. ${ }^{3}$ Department of Internal Medicine, Hematology Section, Haukeland University Hospital, Bergen, Norway.

Published: 28 August 2015

doi:10.1186/1742-4690-12-S1-P8

Cite this article as: Omsland et al: The effect of chemotherapeutics on cell-to-cell transport of HTLV-1 and the $\mathrm{p} 8$ protein through membrane nanotubes. Retrovirology 2015 12(Suppl 1):P8.

Submit your next manuscript to BioMed Central and take full advantage of:

- Convenient online submission

- Thorough peer review

- No space constraints or color figure charges

- Immediate publication on acceptance

- Inclusion in PubMed, CAS, Scopus and Google Scholar

- Research which is freely available for redistribution

Submit your manuscript at www.biomedcentral.com/submit
() Biomed Central 